\title{
Effect of rare earth dopants on structural and mechanical properties of nanoceria synthesized by combustion method
}

Article in Materials Science and Engineering A · October 2015

DOI: 10.1016/j.msea.2015.09.125

CITATIONS

2

5 authors, including:

\section{A. Akbari-Fakhrabadi}

University of Chile

20 PUBLICATIONS 82 CITATIONS

SEE PROFILE

Mahdiyeh Jamshidijam

University of Concepción

13 PUBLICATIONS 25 CITATIONS

SEE PROFILE
READS

78
V. Meruane

University of Chile

39 PUBLICATIONS 199 CITATIONS

SEE PROFILE

Miguel Ángel Gracia Pinilla

Autonomous University of Nuevo León

48 PUBLICATIONS 264 CITATIONS

SEE PROFILE

Some of the authors of this publication are also working on these related projects:

Development on the synthesis, fabrication and characterization of La-based perovskite nanostructures for reversible solid oxide cells View project 


\section{Author's Accepted Manuscript}

Effect of rare earth dopants on structural and mechanical properties of nanoceria synthesized by combustion method

A. Akbari-Fakhrabadi, V. Meruane, M. Jamshidijam, M.A. Gracia-Pinilla, R.V. Mangalaraja

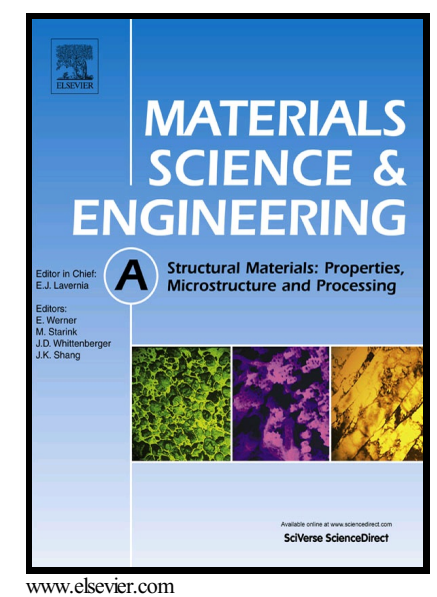

PII: $\quad$ S0921-5093(15)30463-9

DOI: $\quad$ http://dx.doi.org/10.1016/j.msea.2015.09.125

Reference: MSA32851

To appear in: Materials Science \& Engineering A

Received date: 26 June 2015

Revised date: 26 September 2015

Accepted date: 30 September 2015

Cite this article as: A. Akbari-Fakhrabadi, V. Meruane, M. Jamshidijam, M.A. Gracia-Pinilla and R.V. Mangalaraja, Effect of rare earth dopants on structura and mechanical properties of nanoceria synthesized by combustion methoc Materials Science \& Engineering A http://dx.doi.org/10.1016/j.msea.2015.09.125

This is a PDF file of an unedited manuscript that has been accepted fo publication. As a service to our customers we are providing this early version o the manuscript. The manuscript will undergo copyediting, typesetting, an review of the resulting galley proof before it is published in its final citable form Please note that during the production process errors may be discovered whic could affect the content, and all legal disclaimers that apply to the journal pertain 


\title{
Effect of rare earth dopants on structural and mechanical properties of nanoceria synthesized by combustion method
}

\author{
A. Akbari-Fakhrabadi*,a, V. Meruane ${ }^{\mathrm{a}}$, M. Jamshidijam ${ }^{\mathrm{b}, \mathrm{c}}$, M. A. Gracia-Pinilla ${ }^{\mathrm{d}, \mathrm{e}}$, \\ R. V. Mangalaraja ${ }^{\mathrm{b}}$ \\ advanced Materials Laboratory, Department of Mechanical Engineering, University of Chile, Beauchef 851, \\ Santiago, Chile \\ ${ }^{\mathrm{b}}$ Advanced Ceramics and Nanotechnology Laboratory, Department of Materials \\ Engineering, University of Concepcion, Concepcion, Chile \\ ${ }^{c}$ Department of Materials Engineering, Islamic Azad University, Sirjan Branch, Sirjan, Iran. \\ ${ }^{\mathrm{d}}$ Universidad Autónoma de Nuevo León, Facultad de Ciencias Físico-Matemáticas, \\ Av. Universidad, Cd. Universitaria, San Nicolás de los Garza, N.L., México. \\ ${ }^{\text {e}}$ Universidad Autónoma de Nuevo León, Centro de Investigación e Innovación en Desarrollo de Ingeniería y \\ Tecnología, PIIT Km 6, Carretera al Aeropuerto, Apodaca, N.L., México. \\ E-mail: aliakbarif@ing.uchile.cl
}

\begin{abstract}
Structural characteristics of combustion synthesized, calcined and densified pure and doped nanoceria with tri-valent cations of $\mathrm{Er}, \mathrm{Y}, \mathrm{Gd}, \mathrm{Sm}$ and $\mathrm{Nd}$ were analyzed by X-ray diffraction (XRD) and high resolution transmission electron microscopy (HRTEM). The results showed that the as-synthesized and calcined nanopowders were mesoporous and calculated lattice parameters were close to theoretical ion-packing model. The effect of dopants on elastic modulus, microhardness and fracture toughness of sintered pure and doped ceria were investigated. It was observed that tri-valent cation dopants increased the hardness of the ceria, whereas the fracture toughness and elastic modulus were decreased.
\end{abstract}

Keywords: Combustion synthesis; doped ceria; mesoporous; mechanical properties. 


\section{Introduction}

There is a wide range of applications for pure and doped ceria $\left(\mathrm{CeO}_{2}\right)$ such as electrolyte and barrier layers for solid oxide fuel cells (SOFCs) [1,2], catalysts for the treatment of automotive exhaust gases, petroleum cracking catalyst and gas sensor [3,4], polishing materials [5], oxygen pumps, ampere metric oxygen monitors [6,7] and optical films [8] because of their remarkable properties such as high oxygen storage capability $[9,10]$ and ionic conductivity[11]. Besides these physical properties, their mechanical characterizations are also important in design and fabrication especially for mobile and portable devices.

Mechanical properties of ceria doped with different dopants mainly rare earth tri-valent cations prepared by different synthesis processes have been studied by various researchers. For instance, Fu et al. [12] reported microhardness in the range of 6.045-7.378 GPa and fracture toughness in the range of 6.393-7.003 $\mathrm{MPa} \mathrm{m}^{1 / 2}$ for $\mathrm{Ce}_{0.8} \mathrm{M}_{0.2} \mathrm{O}_{2-\delta}(\mathrm{M}=\mathrm{Y}, \mathrm{Gd}, \mathrm{Sm}$, $\mathrm{Nd}, \mathrm{La})$ produced by a coprecipitation method. Sameshima et al. [13] reported 158-178 $\mathrm{GPa}$ of Young's modulus and 53-81 MPa of strength for $\mathrm{Ce}_{0.8} \mathrm{R}_{0.2} \mathrm{O}_{1.9}$ ( $\mathrm{R}=\mathrm{Sm}$ and $\left.\mathrm{La}\right)$ prepared by oxalate coprecipitation method. Morales et al. [14] obtained the Young's modulus in the range of 186-239 GPa, hardness in the range of 10.5-16.9 GPa and fracture toughness in the range of $1.27-1.47 \mathrm{MPa} \mathrm{m}^{1 / 2}$ for various compositions of $\mathrm{Gd}_{\mathrm{x}} \mathrm{Ce}_{1-\mathrm{x}} \mathrm{O}_{2-\mathrm{x} / 2}$ produced by the sol-gel method. There are more reports for mechanical properties of ceria doped with gadolinium and samarium [15-19] in literature due to having higher ionic conductivity which make them potential candidates for electrolyte materials for SOFCs at low operation temperatures. As it can be seen from aforementioned data and as demonstrated by Wachtel and Lubomirsk [20] who reviewed and analyzed the elastic modulus of pure and doped ceria measured by various methods, mechanical properties of ceria are function of chemical composition, the history of the samples and the measurement techniques. Based on our knowledge, there is no report on effect of $\mathrm{Er}^{3+}$ on mechanical properties of ceria.

In this investigation, we prepared $\mathrm{CeO}_{2}$ and $\mathrm{Ce}_{0.9} \mathrm{M}_{0.1} \mathrm{O}_{1.95}(\mathrm{M}=\mathrm{Er}, \mathrm{Y}, \mathrm{Gd}, \mathrm{Sm}$ and $\mathrm{Nd}$ ) nanopowders by combustion technique and studied to compare their structural and mechanical characterizations. 


\section{Experimental}

$\mathrm{CeO}_{2}$ and $\mathrm{Ce}_{0.9} \mathrm{M}_{0.1} \mathrm{O}_{1.95}(\mathrm{M}=\mathrm{Er}, \mathrm{Y}, \mathrm{Gd}, \mathrm{Sm}$ and $\mathrm{Nd})$ nanopowders were synthesized through the nitrate-fuel combustion method by using citric acid as an organic fuel. High purity $(>99.9 \%) \mathrm{Ce}\left(\mathrm{NO}_{3}\right)_{3} \cdot 6 \mathrm{H}_{2} \mathrm{O}, \quad \mathrm{Er}\left(\mathrm{NO}_{3}\right)_{3} \cdot 6 \mathrm{H}_{2} \mathrm{O}, \quad \mathrm{Y}\left(\mathrm{NO}_{3}\right)_{3} \cdot 6 \mathrm{H}_{2} \mathrm{O}, \quad \mathrm{Gd}\left(\mathrm{NO}_{3}\right)_{3} \cdot 6 \mathrm{H}_{2} \mathrm{O}$, $\mathrm{Sm}\left(\mathrm{NO}_{3}\right)_{3} \cdot 6 \mathrm{H}_{2} \mathrm{O}$ and $\mathrm{Nd}\left(\mathrm{NO}_{3}\right)_{3} \cdot 6 \mathrm{H}_{2} \mathrm{O}$, from Sigma-Aldrich, were used as precursor reagents. The details of the synthesis have been reported elsewhere [17, 21, 22]. The assynthesized powders were calcined at $700^{\circ} \mathrm{C}$ for $2 \mathrm{~h}$.

The calcined powders were uni-axially pressed (90 MPa) to fabricate discs with $25 \mathrm{~mm}$ in diameter and $3 \mathrm{~mm}$ in thickness and were sintered at $1400^{\circ} \mathrm{C}$ for $2 \mathrm{~h}$. Structural characterizations of as-synthesized and calcined powders and sintered discs were characterized by X-ray diffraction (XRD, Bruker D8) using TOPAS software. The microstructural features of the nanopowders were analyzed using a high resolution transmission electron microscope (HRTEM, FEI TITAN G2 80-300) operated at $300 \mathrm{kV}$ and scanning transmission electron microscopy high-angle annular dark field (STEMHAADF).

The discs were suspended by soft springs to simulate a "free-free" boundary condition and were excited by an impact hammer. The vibration of the discs is captured by a microphone which was connected to a data acquisition system. A signal processing software computed the frequency content of the measured signals from which the experimental resonant frequencies were identified. This procedure is illustrated in Fig. 1. Once the experimental resonant frequencies were identified, the elastic modulus was computed using the following relationship [23]:

$$
f_{20}=\frac{0.2458 h}{r^{2}} \sqrt{\frac{E}{\rho\left(1-v^{2}\right)}}, \quad f_{01}=1.682 f_{20}
$$

where $\square=0.3$ is poisson's ratio, $h$ and $\mathrm{r}$ are thickness and radius of disc, respectively. The variables $\mathrm{f}_{20}$ and $\mathrm{f}_{01}$ correspond to the first two resonant frequencies of the disc. Fig. 2 presents a scheme of the first two vibration modes, the region in black indicate no displacement whereas the white colour indicates region of maximum displacement. The discs must be excited at a point of large displacement for the mode of interest. Therefore, 
mode $(2,0)$ was excited with an impact near the edge of the disc while the mode $(0,1)$ was excited with an impact in the middle of the disc.

The Vickers microhardness of the sintered discs was measured using Struers microhardness tester under ambient conditions. The hardness was determined by the ratio of the applied load via a geometrically defined indenter to the projected area of the resultant impression using relationship:

$$
H_{v}=\frac{1854.4 P}{a^{2}}
$$

where $P$ is the applied load and $a$ is the indentation diagonal length. In a typical indentation test, load was varied from 5 to $20 \mathrm{~N}$ for a dwelling time of $15 \mathrm{~s}$. At least ten indentations were made for each load on all the samples. The fracture toughness was calculated by the indentation technique using the same instrument. Both diagonal lengths of the indentation images and crack lengths were measured by scanning electron microscopy (SEM) and the fracture toughness $\left(\mathrm{K}_{\mathrm{IC}}\right)$ values were calculated by the method of Palmqvist cracks.

\section{Results and discussion}

The X-ray diffraction patterns of as-synthesized, calcined powders and sintered discs showed fluorite structure with structural characteristics summarized in Tables 1, 2 and 3, respectively. Fig. 3 shows the obtained lattice parameters by Rietveld refinement versus dopant cation radius compared with calculated lattice parameter based on the ion-packing model [24]. As it can be seen, the lattice parameters become close to the theoretical values, decrease in lattice strains and increase in crystallite sizes were observed for both calcinedpowders and sintered discs. Change in the lattice parameter after calcination has been reported for $\mathrm{Fe}$ doped ceria, where it was attributed to the reduction of $\mathrm{Ce}^{4+}$ to $\mathrm{Ce}^{3+}$ due to calcination in hydrogen gas [25]. Based on our results, it seems that it can be related to structural defects reduction during thermal treatment. As examples shown in Figs. 4 and 5, morphology and structure of synthesized and calcined powders studied by using HRTEM and HAADF, which show high crystallinity containing mesopores where structural distortion and dislocations exist. As we reported elsewhere [26], these structural defects are reduced by thermal processing, which confirmed the XRD results. 
To determine the elastic properties of pure and doped ceria, impulse excitation technique as high precision dynamic method [27] was applied. Fig. 6 depicts the experimental power spectral densities of the discs showing two vibration modes. The first and second resonant frequencies of each disc were identified by measuring the response of the discs to an impact in the edge or the middle of the discs, respectively. These frequencies were used along with bulk densities measured by geometrical method in equation 1 to calculate Young's modulus (Table 4). Elastic modulus of oxygen ion conductors such as doped ceria is a function of temperature, porosity, chemical composition and oxygen vacancy concentration which can be expressed as:

$$
E=E_{0} \exp (-4.5 P)
$$

where $\mathrm{E}_{0}$ is the elastic modulus at zero porosity $(\mathrm{P}=0)$. This is an empirical relationship employed by Selcuk and Atkinson [28] and widely used to determine the change of elastic modulus as a function of porosity [15]. As it can be seen in Table 4, $\mathrm{E}_{0}$ of all samples were calculated to avoid the effect of porosity. Elastic modulus of pure ceria is higher than doped ceria samples, which confirmed the previous reports on Y-, Sm- and Gd-doped ceria [29]. Substituting $\mathrm{Ce}^{4+}$ by trivalent dopants creates oxygen vacancies to achieve the electrical neutrality and it has been accepted that the elastic modulus decreases noticeably with increase in the concentration of oxygen vacancy [20]. Among doped ceria samples, EDC samples showed the highest elastic modulus. Sato et al. [30] reported effect of dopant concentration on elastic modulus in which the change is due to the variation of the distance between the cations and bonding forces. Although there is no significant relationship between obtained elastic moduli and bonding energies of different dopants, the higher elastic modulus of EDC can be related to the negative association energy of erbium. As discussed by Shehata et al. [31], all trivalent dopants increase the conversion of cerium from $\mathrm{Ce}^{4+}$ to $\mathrm{Ce}^{3+}$ or increase the oxygen vacancy concentration. However, lanthanide elements with negative association energies like erbium reduce the percentage of cerium that exists in the $\mathrm{Ce}^{3+}$ ionization states and scavenge oxygen vacancies in the synthesized ceria nanoparticles. 
As a property that indirectly reveals the bulk mechanical strength of the sintered ceramics, microhardness of pure and doped ceria samples were measured and compared as shown in Fig. 7. All doped ceria samples showed higher hardness than pure ceria, which is in agreement with the reported results in literature [29]. EDC sample demonstrated the highest hardness that could be related to improving the atomic bonds by doping ceria with Er as it was seen in elastic modulus measurement earlier and YDC samples has the lowest hardness among doped ceria samples, which could attributed to lower density due to having high porosity $[15,19]$.

As an example, Fig. 8 shows the indentation mark observed on the samples. The cracks observed near the indentation zones were used to calculate the indentation fracture toughness. As reported by Ponton and Rawlings [32], there are many equations with some conditions and limitations proposed for measuring indentation fracture toughness. For comparison purpose, fracture toughness was determined by Niihara's[33], Laugier's[34], Anstis's [35]and Evan's [36] equations. As graphed in Fig. 9, doping ceria with trivalent cations decreased its fracture toughness. Maschio et al. [37] reported $\mathrm{K}_{\mathrm{IC}}$ of $\mathrm{CeO}_{2}$ measured by the notch-beam technique, which is close to the fracture toughness obtained by Evan's equation. As suggested by Morales et al. [14] and Sato et al. [29] who reported the effect of dopant content on fracture toughness of doped ceria, decrease in the fracture toughness of doped ceria can be due to an increased oxygen vacancy density generated by the dopants.

\section{Conclusion}

Pure and Er, Y, Gd, Sm and Nd doped ceria nanopowders synthesized by citrate-nitrate auto-combustion route were calcined and densified to discs. Structural characteristics of nanopowders showed that they were mesoporous which were decreased by calcination. The results of elastic modulus and microhardness measurement showed that doping with erbium enhanced the mechanical properties of ceria than other dopants. Nevertheless, all dopants decreased fracture toughness of ceria. 


\section{Acknowledgements}

The authors acknowledge FONDECYT, Government of Chile (Project No.: 3140180 and 1130916), for the support to carry out this project. Gracia-Pinilla thank to CONACyT for financial support at the Programa de Estancias Sabáticas al Extranjero, Grant 234104.

\section{References}

[1] A. Akbari-Fakhrabadi, R.V. Mangalaraja, F.A. Sanhueza, R.E. Avila, S. Ananthakumar, S.H. Chan, J. Power Sources 218 (2012) 307-312.

[2] M.J. López-Robledo, M.A. Laguna-Bercero, J. Silva , V.M. Orera, A. Larrea, Ceram. Int. 41 (2015) 7651-7660.

[3] B. Matovic, Z. Dohcevic-Mitrovic,M. Radovic, Z. Brankovic, G. Brankovic, S. Boskovic, Z.V. Popovic, J. Power Sources 193 (2009) 146-149.

[4] M.R. Kosinski, R.T. Baker, J. Power Sources 196 (2011) 2498-2512.

[5] S. Chandramouleeswaran, S.T. Mhaske, A.A. Kathe, P.V. Varadarajan, V. Prasad, N. Vigneshwaran, Nanotechnology 18 (2007) 385702-385710.

[6] J.G. Li, T. Ikagami, J.H. Lee, T. Mori, Acta Mater. 49 (2001) 419-426.

[7] A.I.Y. Tok, S.W. Du, F.Y.C. Boey, W.K. Chong, Mater. Sci. Eng. A 466 (2007) 223229.

[8] D. Barreca, A. Gasparotto, C. Maccato, C. Maragno, E. Tondello, E. Comini, G. Sberveglieri, Nanotechnology 18 (2007) 125502-125508.

[9] A. Trovarelli, Catal. Rev. Sci. Eng. 38 (1996) 439-520.

[10] A. Trovarelli, P. Fornasiero, Catalysis by Ceria and Related Materials, $2^{\text {nd }}$ edition, Imperial College Press, 2013.

[11] B.C.H. Steele, Solid State Ionics 129 (2000) 95-110.

[12] Y.P. Fu, S.H. Chen, J.J. Huang, Int. J. hydrogen energy 35 (2010) 745-752.

[13] S. Sameshima, T. Ichikawa, M. Kawaminami, Y. Hirata, Mat. Chem. and Phy. 61 (1999) 31-35.

[14] M. Morales, J.J. Roa, X.G. Capdevila, M. Segarra, S. Piñol, Acta Mater. 58 (2010) 2504-2509. 
[15] X.F. Fan, E.D. Casen, Q. Yang, J.D. Nicholas, Ceram. Int. 39 (2013) 6877-6886.

[16] R. Korobko, C. Chen, S. Kim, S.R. Cohen, E. Wachtel, N. Yavoa, I. Lubomirsky, Scripta Mat. 66 (2012) 155-158.

[17] R.V. Mangalaraja, S. Ananthakumar, K. Uma, R. M. Jiménez, M. López, C. P. Camurri, Mat. Sci. and Eng. A 517 (2009) 91-96.

[18] R.V. Mangalaraja, S. Ananthakumar, Anke Schachtsiek, M. López, C. P. Camurri, R. E. Avila, Mat. Sci. and Eng. A 527 (2010) 3645-3650.

[19] A. Akbari-Fakhrabadi, R. V.Mangalaraja, M. Jamshidijam, S. Ananthakumar, S. H. Chan, Fuel Cells 13 (2013) 682-688.

[20] E. Wachtel, I. Lubomirsky, Scripta Mat. 65 (2011) 112-117.

[21] M. Jamshidijam, R.V. Mangalaraja, A. Akbari-Fakhrabadi, S. Ananthakumar, S.H. Chan, Powder Tech. 253 (2014) 304-310.

[22] A. Akbari-Fakhrabadi, R.E. Avila, H.E. Carrasco, S. Ananthakuma, R.V. Mangalaraja J Alloys Comp., 541 (2012) 1-5.

[23] L. Meirovitch Analytical methods in vibration. New York, NY.: The Mcmillan Company 19 (1967).

[24] S.J. Hong, A.V. Virkar, J. Am. Ceram. Soc. 78 (1995) 433-439.

[25] H. Lv, H. Tu, B. Zhao, Y. Wu, K. Hu, Solid State Ionics 177 (2007) 3467-3472.

[26] A. Akbari-Fakhrabadi, R.V. Mangalaraja, M.A. Gracia Pinilla, M. Jamshidijam, S.H. Chan, Mat. Lett. 125 (2014) 19-24.

[27] M. Radovic, E. Lara-Curzio, L. Riester, Mat. Sci. Eng. A 368 (2004) 56-70.

[28] A. Selcuk, A. Atkinson, J. Europ. Ceram. Soc. 17 (1997) 1523-1532

[29] K. Sato, H. Yugami, T. Hashida, J. Mater. Sci. 39 (2004) 5765-5770.

[30] K. Sato, K. Suzuki, K. Yashiro, T. Kawada, H. Yugami, T. Hashida, A. Atkinson, J Mizusaki, Solid State Ionics 180 (2009) 1220-1225.

[31] N. Shehata, K. Meehan, M. Hudait, N. Jain, J. Nanopart Res. 14 (2012) 1173-1183.

[32] B.C. Ponton, R.D. Rawlings, Mater. Sci. Technol. 5 (1989) 865-872.

[33] K. Niihara, R. Morena, D.P.H. Hasselman, J. Mater. Sci. Lett. 2 (1983) 221-223.

[34] M.T. Laugier, J. Mater. Sci. Lett. 4 (1985) 1539-1541.

[35] G.R. Anstis, P. Chantikul, B.R. Lawn, D.B. Marshall, J. Am. Ceram. Soc. 64 (1981) 539-543. 
[36] A.G. Evans, E.A. Charles, J. Am. Ceram. Soc. 59 (1976) 371-372.

[37] S. Maschio, O. Sbaizero, S. Meriani, J. Europ. Ceram. Soc. 9 (1992) 127-132.

\section{Tables and figures Captions}

Table 1. The structural parameters of synthesized pure and RE-doped ceria.

Table 2. The structural parameters of calcined pure and RE-doped ceria at $700^{\circ} \mathrm{C} / 2 \mathrm{~h}$

Table 3. The structural parameters of sintered pure and RE-doped ceria discs at $1400^{\circ} \mathrm{C} / 4 \mathrm{~h}$

Table 4. Physical properties of pure and RE-doped ceria discs sintered at $1400^{\circ} \mathrm{C} / 4 \mathrm{~h}$

Fig. 1. Experimental setup of impulse tests on discs.

Fig. 2. First two discs vibration modes.

Fig. 3. Measured lattice parameter of synthesized, calcined powders and sintered discs of pure and doped ceria versus doped cation radius.

Fig. 4. HRTEM images of synthesized and calcined SDC nanopowders.

Fig. 5. (a) HRTEM Images of $\mathrm{Nd}$ Doped $\mathrm{CeO}_{2}$, the squares indicate the porous inside of the nanocrsytals, (b) SAED indexed pattern, (c) HRTEM Images of Nd Doped $\mathrm{CeO}_{2}$, (111) with $3.19 \AA$ and DDP insert of the nanoparticles in the image indexed to the [011] zone axis of the fluorite structure and with shown Miller indices, (d) High magnification image of HAADF-STEM showing NDC nanoparticles.

Fig. 6. Power spectral density showing two vibration modes of sintered disc samples.

Fig. 7. Microhardness of sintered discs as a function of load.

Fig. 8. Vickers indentation mark on EDC sintered disc.

Fig. 9. Fracture toughness measured with Niihara, Laugier, Anistis and Evan's Eqs At $10 \mathrm{~N}$ applied load for sintered discs. 
Table 1.

\begin{tabular}{ccccccccc}
\hline & $\mathrm{a}(\mathrm{nm})$ & $\mathrm{D}(\mathrm{nm})$ & Strain & $\rho\left(\mathrm{gcm}^{-3}\right)$ & $\mathrm{R}_{\exp }(\%)$ & $\mathrm{R}_{\mathrm{wp}}(\%)$ & $\mathrm{R}_{\mathrm{p}}(\%)$ & $\mathrm{GOF}$ \\
\hline Ceria & 5.4158 & 17.1 & 0.2405 & 7.197 & 2.03 & 2.44 & 1.89 & 1.20 \\
\hline EDC & 5.4030 & 39.8 & 0.1307 & 7.248 & 11.25 & 12.18 & 8.53 & 1.08 \\
\hline YDC & 5.4062 & 14.2 & 0.3690 & 7.235 & 12.38 & 14.21 & 10.32 & 1.15 \\
\hline GDC & 5.4147 & 15.8 & 0.4334 & 7.201 & 10.96 & 11.91 & 8.35 & 1.09 \\
\hline SDC & 5.4278 & 9.7 & 0.8440 & 7.149 & 11.30 & 11.91 & 8.90 & 1.05 \\
\hline NDC & 5.4277 & 16.3 & 0.4747 & 7.149 & 11.45 & 12.29 & 8.97 & 1.07 \\
\hline
\end{tabular}

Table 2.

\begin{tabular}{ccccccccc}
\hline & $\mathrm{a}(\mathrm{nm})$ & $\mathrm{D}(\mathrm{nm})$ & Strain & $\rho\left(\mathrm{gcm}^{-3}\right)$ & $\mathrm{R}_{\exp }(\%)$ & $\mathrm{R}_{\mathrm{wp}}(\%)$ & $\mathrm{R}_{\mathrm{p}}(\%)$ & $\mathrm{GOF}$ \\
\hline Ceria & 5.4129 & 32.1 & 0.0705 & 7.208 & 2.12 & 3.47 & 2.74 & 1.64 \\
\hline EDC & 5.4035 & 38.7 & 0.1066 & 7.246 & 13.11 & 13.07 & 9.53 & 1.14 \\
\hline YDC & 5.4049 & 37.5 & 0.1044 & 7.240 & 12.39 & 14.00 & 9.88 & 1.13 \\
\hline GDC & 5.4123 & 49.6 & 0.0901 & 7.211 & 11.98 & 13.65 & 9.63 & 1.14 \\
\hline SDC & 5.4260 & 50.7 & 0.1305 & 7.156 & 11.65 & 11.98 & 7.77 & 1.03 \\
\hline NDC & 5.4251 & 36.5 & 0.1584 & 7.160 & 12.21 & 13.66 & 9.64 & 1.12 \\
\hline
\end{tabular}

Table 3.

\begin{tabular}{ccccccccc}
\hline & $\mathrm{a}(\mathrm{nm})$ & $\mathrm{D}(\mathrm{nm})$ & Strain & $\rho\left(\mathrm{gcm}^{-3}\right)$ & $\mathrm{R}_{\exp }(\%)$ & $\mathrm{R}_{\mathrm{wp}}(\%)$ & $\mathrm{R}_{\mathrm{p}}(\%)$ & $\mathrm{GOF}$ \\
\hline Ceria & 5.4121 & 59.4 & 0.0558 & 7.211 & 2.70 & 11.24 & 7.93 & 4.16 \\
\hline EDC & 5.4078 & 53.2 & 0.0701 & 7.229 & 5.42 & 12.17 & 9.09 & 2.25 \\
\hline YDC & 5.4084 & 52.0 & 0.0000 & 7.226 & 5.63 & 12.66 & 9.56 & 2.25 \\
\hline GDC & 5.4200 & 51.6 & 0.0839 & 7.173 & 5.21 & 10.15 & 7.55 & 1.95 \\
\hline SDC & 5.4216 & 60.1 & 0.0000 & 7.174 & 5.34 & 11.71 & 8.81 & 2.20 \\
\hline NDC & 5.4301 & 67.6 & 0.0000 & 7.140 & 5.52 & 13.95 & 10.48 & 2.53 \\
\hline
\end{tabular}

Table 4.

\begin{tabular}{ccccccc}
\hline & $\begin{array}{c}\mathrm{f}_{20} \times 10^{4} \\
(\mathrm{~Hz})\end{array}$ & $\begin{array}{c}\mathrm{f}_{01} \times 10^{4} \\
(\mathrm{~Hz})\end{array}$ & $\begin{array}{c}\text { Measured } \\
\text { density }\left(\mathrm{gcm}^{-3}\right)\end{array}$ & $\begin{array}{c}\text { Relative density } \\
(\%)\end{array}$ & $\begin{array}{c}\mathrm{E} \\
(\mathrm{GPa})\end{array}$ & $\begin{array}{c}\mathrm{E}_{0} \\
(\mathrm{GPa})\end{array}$ \\
\hline Ceria & 1,59 & 2,69 & 7.022 & 97.4 & 210.3 & 236.7 \\
\hline EDC & 1,57 & 2,66 & 7.057 & 97.7 & 201.4 & 224.2 \\
\hline YDC & 2,674 & 4,54 & 6.806 & 94.2 & 165.9 & 215.4 \\
\hline GDC & 2,24 & 3,78 & 7.169 & 99.9 & 199.7 & 200.2 \\
\hline SDC & 2,27 & 3,82 & 7.105 & 99.1 & 198.6 & 207.4 \\
\hline NDC & 1,74 & 2,94 & 6.903 & 96.7 & 195.3 & 226.8 \\
\hline
\end{tabular}




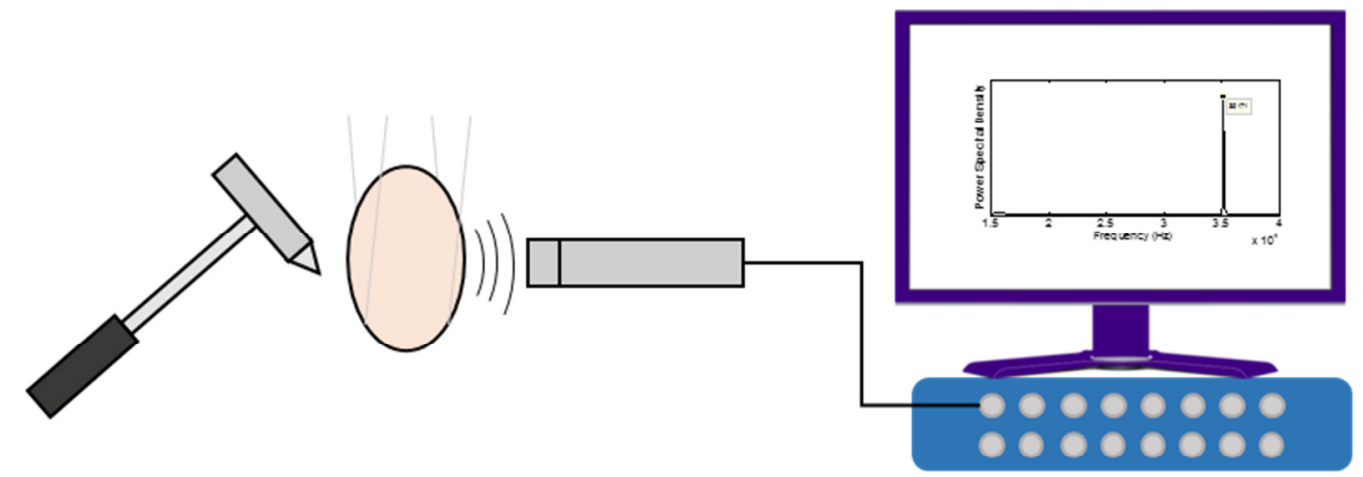

Impact hammer Sample Microphone Data acquisition and signal processing

Fig. 1.

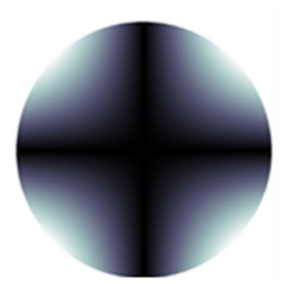

$(2,0)$

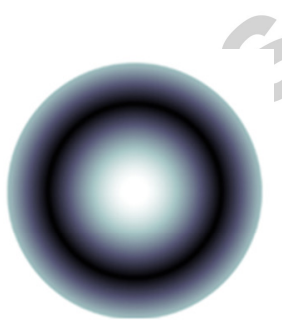

$(0,1)$

Fig. 2. 


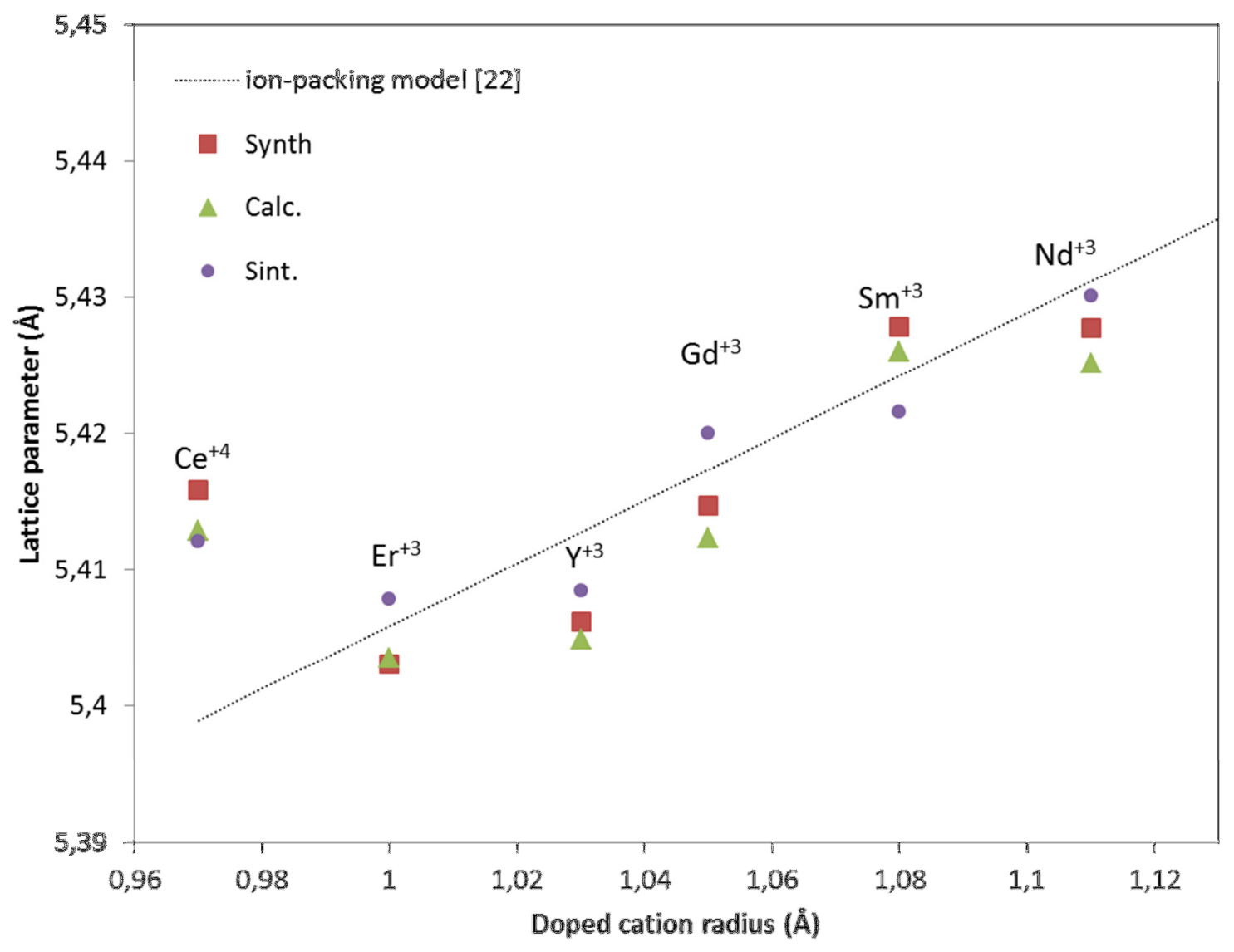

Fig. 3. 


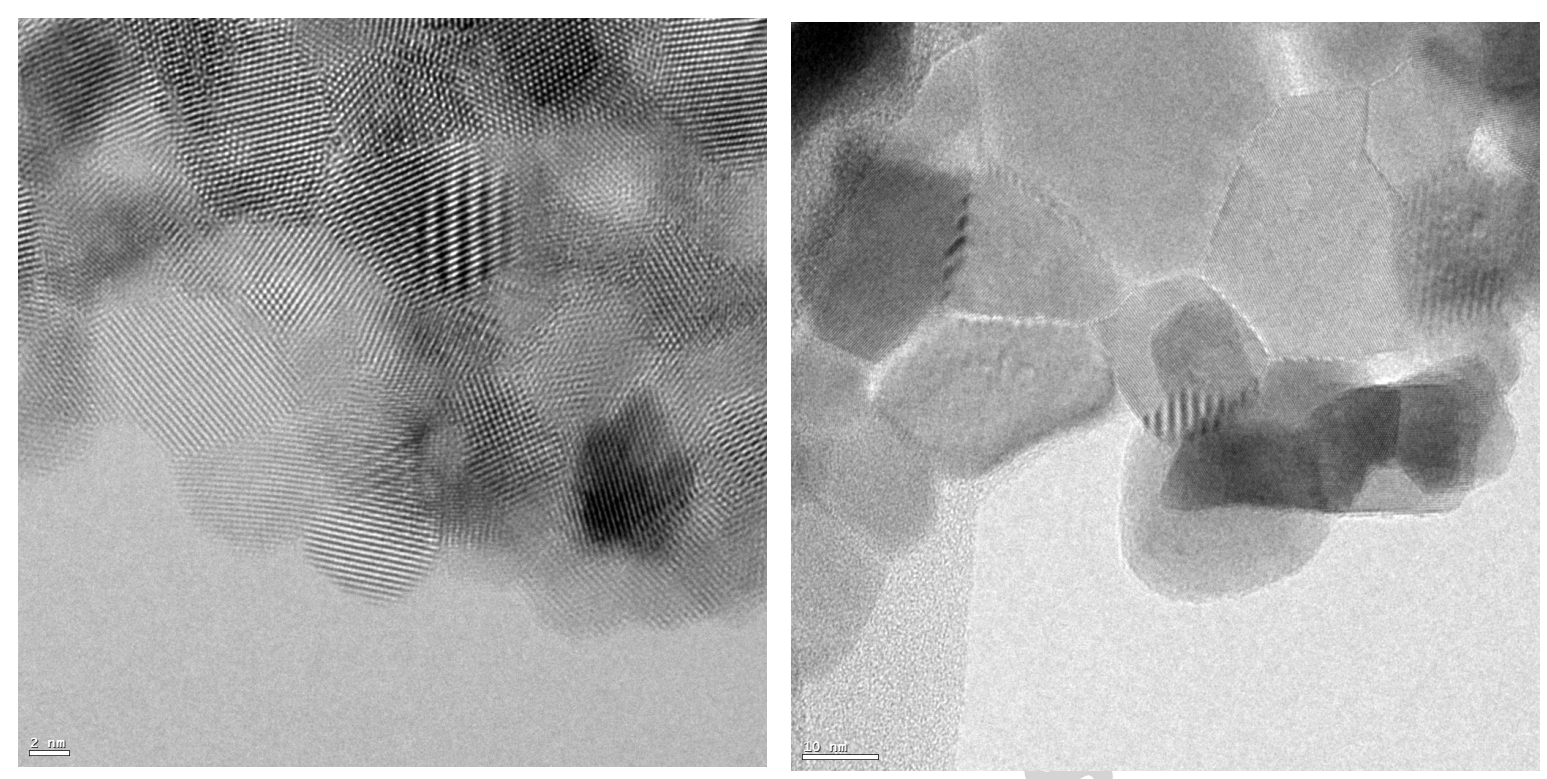

Fig. 4. 

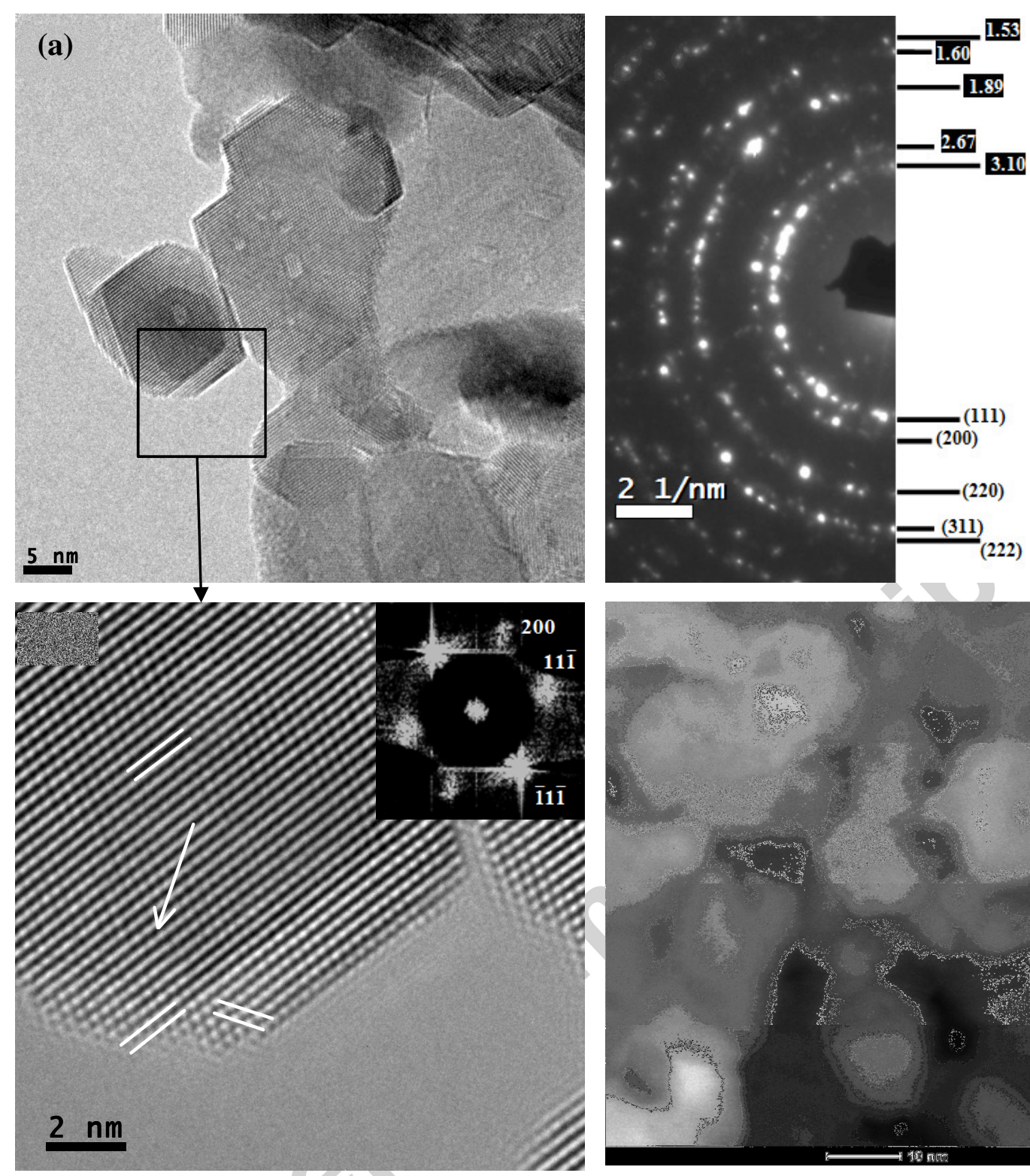

Fig. 5. 
(a)

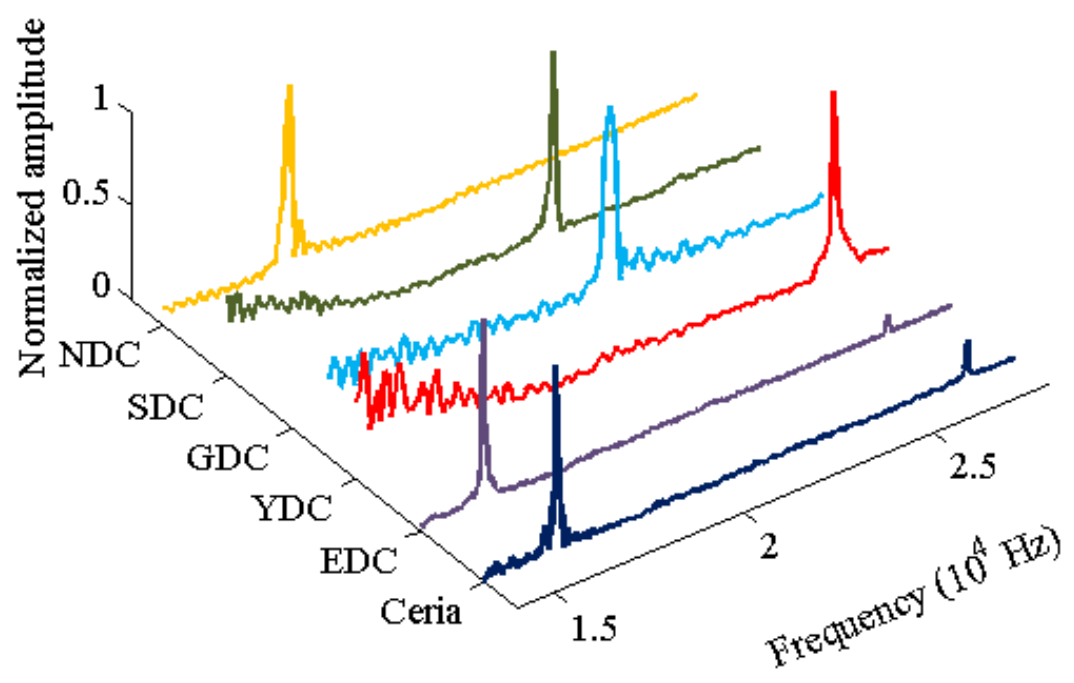

(b)

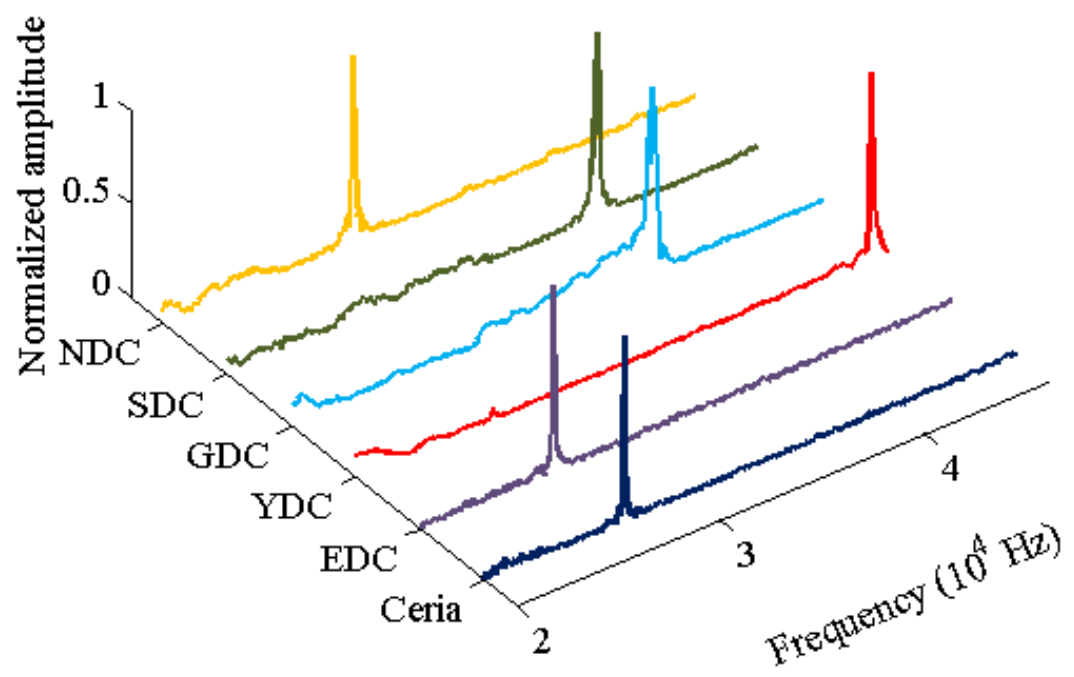

Fi g. 6. 


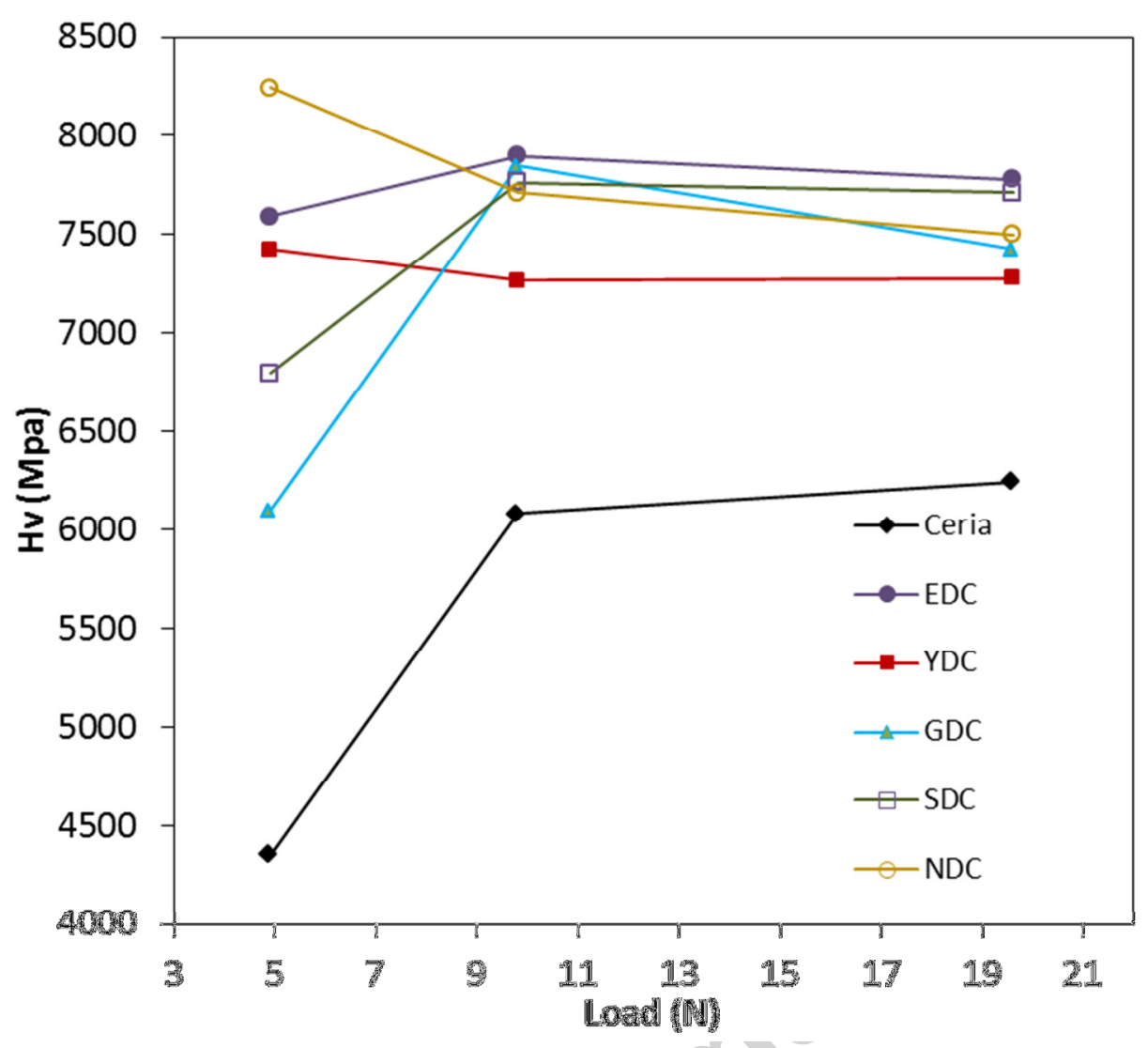

Fig. 7.

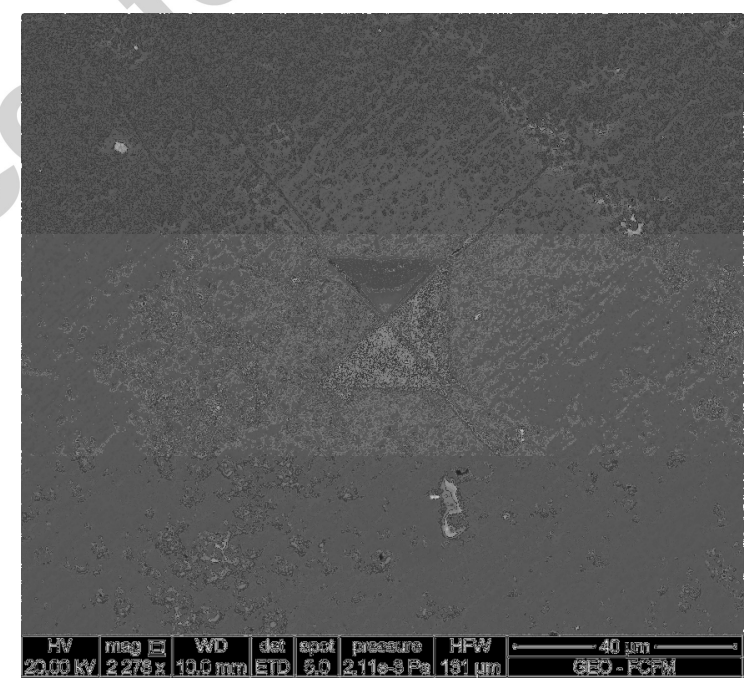

Fig. 8. 


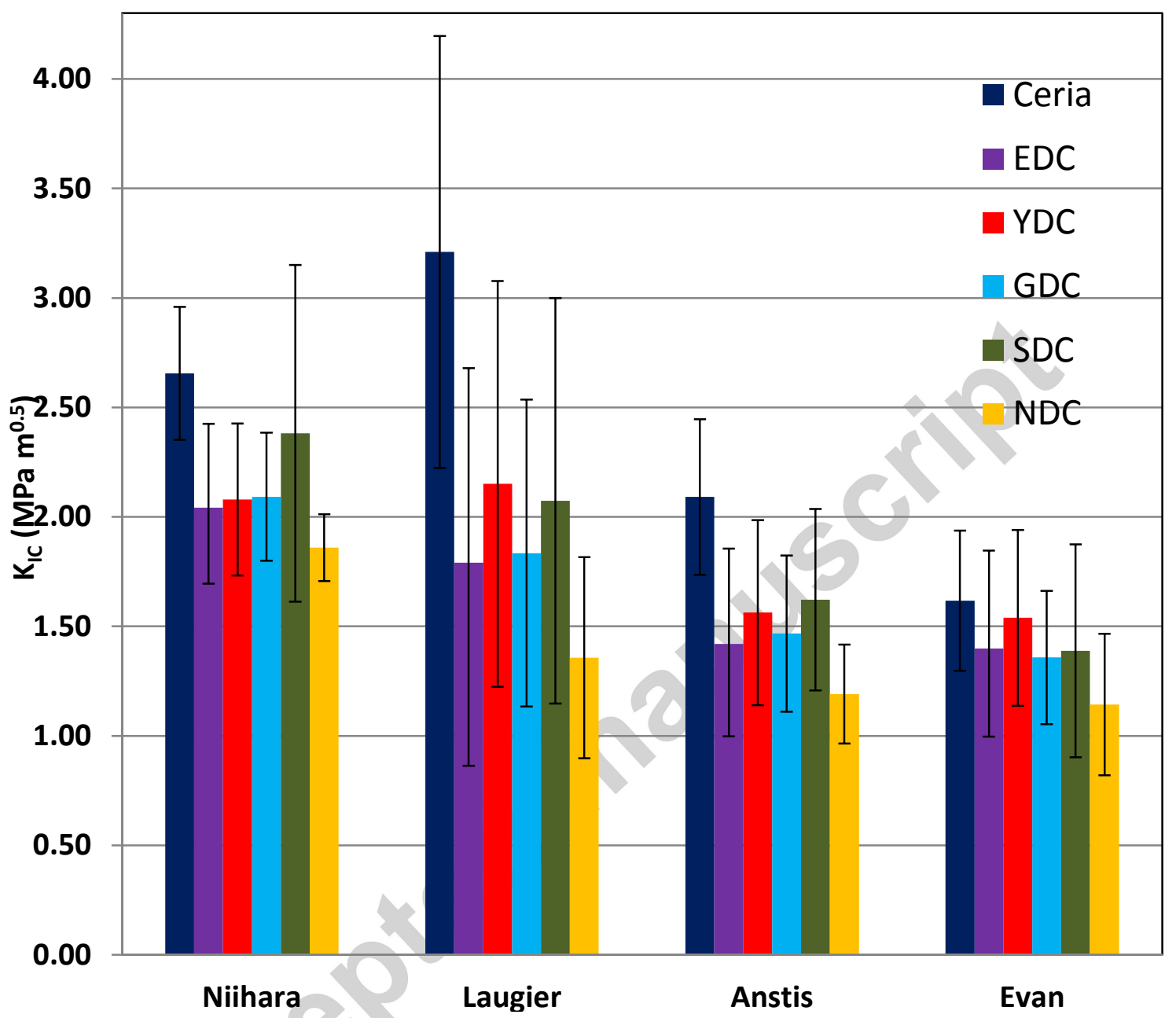

Fig. 9. 